\title{
JEZZYKOZNAWSTWO
}

Jolanta Chomko

DOI 10.15290/sw.2019.19.21

Uniwersytet w Białymstoku

Wydział Filologiczny

Instytut Filologii Wschodniosłowiańskiej

Tel. +48 857457450

e-mail: j.chomko@uwb.edu.pl

ORCID ID: https://orcid.org/0000-0003-0289-7221

\section{Kolor w opisie postaci \\ (na podstawie Drogi do nikqd Aleksandra Grina)}

Słowa kluczowe: Grin, idiolekt pisarza, semantyka barw, kolorysystyka bohaterów

\section{Uwagi wstępne}

Wyrażenia określające barwę są jednym ze środków artystycznych, które pozwalają odbierać utwór literacki jako całość. Leksyka kolorystyczna wyraża myśli autora utworu, wskazuje nie tylko na znaczenie, ale pozwala też wniknąć w sferę emocjonalną i psychikę pisarza w momencie tworzenia dzieła. Wykorzystywane przez pisarza nazwy kolorów stają się symbolami, porównaniami, metaforami, które demonstrują jego stosunek do opisywanego przedmiotu czy zjawiska. Każdy z nich zajmuje swoje określone miejsce w utworze, a jego wybór może być uwarunkowany tematyką, problematyką, oraz tym, w jaki sposób pisarz chce oddziaływać na czytelnika. W związku z powyższym wciąż nie tracą na aktualności badania leksyki kolorystycznej występującej w utworach literackich, a problematyka opisu człowieka, który nie jest istotą bezbarwną [Kul'pina 2001], przy pomocy nazw barw jest ciągle aktualna w świetle idei antropocentryczności języka. Środkom i sposobom kreowania kolorystycznych portretów człowieka poświęcone są, między innymi, prace W.G. Kulpiny [Kul'pina 2001], A. Spólnik [Spólnik 1994], 
K. Siekierskiej [Siekierska 1988], A.I. Gielajewej [Gelâeva 2002] i T.M. Gajdukowej [Gajdukova 2008].

\section{O utworze Droga do nikad}

Celem rozważań w niniejszym artykule będzie spojrzenie na strukturę i semantykę nazw kolorów tworzących przestrzeń barwną bohaterów ostatniej powieści A. Grina Droga do nikad. Pomysł tytułu utworu zrodził się po obejrzeniu przez pisarza na wystawie ryciny, która przedstawiała droge znikająca za opustoszałym wzgórzem i nosiła tytuł Droga do nikąd. Jest to najmniej fantastyczne i najbardziej smutne dzieło tego autora.Tyrreusza Davenanta, głównego bohatera utworu, los konfrontuje z tymi, którzy mają władzę i są bogaci. Jego droga życiowa jest ścieżką rozczarowania, na której został zdradzony, oszukany, uwięziony i osamotniony. Powieść ta, jak żadna z poprzednich prac, jest przepełniona treściami społecznymi. Przy całym swoim krytycznym stosunku do tej sfery, Grin nie przedstawia ich wszystkich w ciemnych barwach - oni też są różni. W rodzinie Futroza chłopiec był dobrze przyjęty, zapraszano go do domu i opiekowano się nim. Syn gubernatora Van Koneta, z kolei, obraziwszy młodego człowieka, wsadza go do więzienia, gdzie ten umiera. Wydawałoby się, że są to dwie zupełnie odmienne postawy wobec drugiego człowieka, a w gruncie rzeczy są one takie same. Futroz i jego córki zainteresowali się chłopcem jako żywą zabawką, a kiedy zabawka zniknęła, nikt o niej nie pamiętał. Dla Van Koneta Davenant jest także zabawką, ale kiedy młody człowiek przeciwstawił się, został zniszczony.

Nawet prości ludzie w tej powieści nie są tak dobrzy, jak to było we wcześniejszych utworach Grina: słudzy Davenanta, Firs i Petronia, opuścili powierzony im hotel i ukryli się ze skradzionymi pieniędzmi, Barket i jego córka odmówili zeznań na rzecz Davenanta w jego sporze z Van Konetem. Zarówno ludzie bogaci, jak i biedni, którzy zdradzili bohatera, są ludźmi przyziemnymi, pozbawionymi romantyzmu. Głównym celem w ich życiu jest władza i bogactwo. Aby to osiągnąć, są gotowi na wszystko - zbrodnię, podłość, czy kłamstwo. I tylko przemytnicy, człowiek nie posiadający określonego zajęcia - Galeran i dziwny kupiec Stomador są romantykami w najlepszym rozumieniu tej ludzkiej cechy, która była typowa dla Grina. Pozostają wiernymi i szlachetnymi przyjaciółmi głównego bohatera utworu do końca, ryzykując wszystko, aby go uratować. W Drodze do nikąd bohater romantyczny ponosi całkowitą klęskę, ponieważ jest samotnikiem, a jego droga życiowa jest właśnie tą drogą do nikąd. 


\section{Kręgi tematyczne barw}

Nazwy barw w Drodze do nikad grupują się w kilku kręgach tematycznych. Znaczna ich część odnosi się do człowieka. Ponad połowa nazw kolorów określających człowieka została wykorzystana przez pisarza do opisu wyglądu zewnętrznego bohaterów: ich twarzy, a więc cery (29 użyć), oczu (16), zębów (2), ust (1) i nosa (1), a także włosów (29), brwi (2), rzęs (1) i zarostu mężczyzn (4). Wyjątkowo określenia barwne dotyczą szyi (1), rąk (1), paznokci (1) czy nogi (1).

Dużą grupę stanowią również nazwy kolorystyczne, które posłużyły do opisu ubiorów: garnitur (11), kapelusz (5), bluzka (3), kurtka (3), pantofle (3), sukienka (2), marynarka (2), spodnie (2), pończochy (2), chustka (2), parasolki (2), kostium (1), koszula (1), szalik (1), mantyla (1), bluza (1), żakiet (1). Sporadycznie w analizowanym utworze barwy odnoszą się do psychologicznego portretu bohaterów (2).

\section{Barwa twarzy bohaterów powieści}

W ostatniej swojej powieści A. Grin dużo uwagi poświęcił barwie twarzy bohaterów, która jest integralną częścią wyglądu postaci. Jak zauważa I. Vaňková, „skóra ludzka (nie biorąc pod uwagę kontekstów, w których są tematyzowane różne typy pigmentu w zakresie różnic rasowych lub różnic w obrębie jednej rasy) niewątpliwie należy również do tzw. obiektów bezbarwnych. O różnych sposobach zabarwienia skóry mówimy jedynie wtedy, kiedy jest ono relewantne w komunikacji językowej, tzn. odbiegające od stanu naturalnego" [Vaňková 2000, 106]. Przedstawiona przez Grina kolorystyka cery jest zarówno cechą stałą występujących osób (naturalnym dla danej postaci kolorem), jak też zmienia się w zależności od stanu emocjonalnego

opisywanej osoby. Kolor twarzy jest zależny od doznań emocjonalnych oraz nastróju i stanu psychicznego człowieka. Przedstawiona przez pisarza gama odczuć doświadczanych przez bohaterów Drogi do nikad jest dość szeroka, można zaliczyć do nich zarówno emocje negatywne, np.: zakłopotanie, zawstydzenie, zdenerwowanie, wzburzenie, zdziwienie, strach, jak i pozytywne, np.: zadowolenie, szczęście, podniecenie. Wpływ na kolorystkę twarzy mogą mieć także czynniki zewnętrzne. Dominującą rolę w opisach cery występujących w powieści postaci, odgrywają nazwy barw z pola czerwieni, sporadycznie pojawiają się barwy z pola bieli i żółcieni.

Nazwy kolorów posłużyły pisarzowi do opisu naturalnego, stałego kolorytu twarzy wyłącznie postaci drugoplanowych. Opisy twarzy głównych 
bohaterów pojawiają się tylko w sytuacjach, w których dochodzi do zmiany jej barwy.

Jedną z postaci drugoplanowych jest młoda dziewczyna Marta, córka Barketa. W kreacji jej obrazu wyjatkową rolę pełni barwa różowa, konotując takie cechy jak niewinność i świeżość, co przedstawia następujący fragment: - По-моему, этот Стомадор какой-то ненормальньий тип! - заметила круглоличая розовая Марта, поклоннича вещей ясных и точных (Utw. 5, 434), Ван-Конет хотел пропустить вопрос мимо ушей, но заметил розовое лицо Mapmbы (Utw. 5, 439).

Różowa jest również twarz człowieka przypadkowo spotkanego przez Davenanta w drodze do Futrozów: - Четьире минуты девятого, - сказал ему наконеи словоохотливый человек с розовыми моршинистыми шеками (Utw. 5, 382).

Z kolei strażnik więzienny Krawar i Tromp - znajomy młynarzy, którzy podwieźli samochodem Davenanta, mają twarze purpurowe: За ними стоял плотный, коренастый Кравар. Его багровое лиџо с седыми бровями показалось между железных прутьев (Utw. 5, 491), - Надо же отдохнуть, чудак. Мы хотим ужинать. Тебе очень не терпится? О! - вскрикнул он, уставившись на подошедшего $\kappa$ группе приезжих огромного человека с багровым личом (Utw. 5, 424). Natomiast właściciel samochodu, który zabrał podążającego do Lissy Davenanta, charakteryzuje się rumianymi policzkami: - Почему ты знаешь, куда мы едем? - спросил третий, черноусый и краснощекий хозяин автомобиля (Utw. 5, 422).

Przy pomocy leksemu желтый został przedstawiony naturalny kolor twarzy handlarza, właściciela szynkwasu, którego jeden z głównych bohaterów - Galeran spotkał w Tachenbaku oraz twarz Futroza, potentata finansowego, ojca Elly i Roeny. Cera szynkarza odróżnia się od cery pozostałych bohaterów i wskazuje na to, że jest on przedstawicielem rasy odmiennej niż rasa biała, południowego typu urody: Эmо был обросший черньми волосами человек с желтылм личом - итальянеи смешанной крови (Utw. 5, 509). Żółtawy odcień twarzy Futroza może odzwierciedlać zmęczenie i przepracowanie: Его черные волосы спускались бакенами до средины щек, придавая одутловатому бритому личу с большим ртом и желтылм оттенком кожи характерную остроту (Utw. 5, 359).

W większości wykreowanych przez autora obrazów bohaterów nazwy kolorów określają cerę nienaturalną, pojawiającą się u człowieka w momencie niekontrolowanej, silnej reakcji na jakiś bodziec. Najczęściej do tych zmian dochodzi pod wpływem silnych emocji. W powieści Droga do nikad 
występują bohaterowie, których twarze zmieniają kolor w wyniku odczuwanego przez nich zakłopotania i zawstydzenia. Sa to wyłącznie osoby młode, niedoświadczone. Należy do nich Marta - córka Barketa, którą krępuje rozmowa z Van Konetem: Марта покраснела под прищуренным на нее взглядом Ван-Конета и без нужды переместила тарелку (Utw. 5, 439), - Отеи! - воскликнула, краснея от смущения, Марта (Utw. 5, 442), Она умолкла. Одно дело - произносить наедине с собой пылкие и обширные речи, другое - говорить о своих желаниях внимательному, замкнутому Ван-Конету. Поняв, ито красноречие ее иссякло, девуика покраснела и закрыла руками личо (Utw. 5, 454). Melly czerwieni się pod wpływem słów Roeny: Рой стала шептать ей на ухо, и Мели покраснела, а Давенант рассльшал окончание шепота: «...раскройте сумочку» (Utw. 5, 376).

Z sytuacjami, które wywołują zmianę kolorystyki twarzy spowodowaną zakłopotaniem, mają do czynienia również młodzi mężczyźni. Widoczne jest to na przykładzie głównego bohatera - Davenanta, który wiele razy jest zawstydzany przez bogatą dziewczynkę Roenę: Давенант ответил не сразу. Он сильно покраснел, выразив бегльм движением лица нестерпимое желание удачи (Utw. 5, 353), - О да! - ласково ульбнулась Рой краснеюшему Давенанту (Utw. 5, 363).

Ważnym i stosunkowo często występującym czynnikiem, wywołującym zaczerwienienie u bohaterów powieści Droga do nikad okazało się zdenerwowanie. Zdenerwowanie połączone z oburzeniem to powód zmiany koloru twarzy Uranii - guwernantki Roenny i Elly: Она сразу узнала Давенанта, но, узнав, покраснела от возмущения (Utw. 5, 378). Zdenerwowana i rozczarowana jest Elly, gdy okazało się, że nie trafiła strzelając do celu: - Чmo? Я попала? - сказала Элли, затем, вся красная, со слезами в глазах, осторожно положила винтовочку на ковер и ушла $\kappa$ дивану, где села, схватила отиа за плечо и, спрятав лищо на его груди, расхохоталась (Utw. 5, 393). Podobnych emocji doświadcza również gubernator Van Konet w rozmowie z synem: Ван-Конет покраснел (Utw. 5, 479). Czerwieni się także zdenerwowana Katrin, kiedy zbyt długo czeka na Stomadora. Na jej policzkach pojawiają się wypieki, które niewątpliwie świadczą o dużych eтосјасh: Значительно посмотрев на нее в упор большими глазами, Стомадор прямо опустил ей в руку два золотьх, и красные пятна щек Катрин всползли до висков (Utw. 5, 490).

Twarz może zmieniać kolor pod wpływem zdziwienia. Przykładem tego typu reakcji jest Felton, który czerwieni się usłyszawszy wyznanie Van Koneta, że to on doprowadził do uwięzienia Gravelota: - Недурно! - сказал Фельтон, смешавшись и краснея от такого признания (Utw. 5, 564). 
Zupełnie innym rodzajem emocji, które wpływają na zmianę kolorystyki cery, jest strach i odczuwalna ze strony rozmówcy pogarda. Przeżywa to Van Konet, kiedy żąda pieniędzy od żony: Чек будет готов, как только вы извините меня, - ответила Консуэло без колебания, иже не мучаясь этой новой низостью, но так внимательно рассматривая мужа, что он слегка покраснел (Utw. 5, 536).

Jedną z przyczyn, które mogą powodować zmiany w kolorze skóry, jest również wzburzenie. Właśnie takich emocji doświadcza Galeran, kiedy czyta list od znajdującego się w więzieniu Davenanta (Gravelota): Галеран с сомнением поднес бумажку к глазам, но лишь прочел о золотой монете, взятой на игру у Давеванта, как страшно оживился, даже покраснел от волнения (Utw. 5, 496).

Sporadycznie Grin wykorzystał nazwy barw do opisu osób, u których zmianę kolorystyki twarzy wywołały przyjemne, pozytywne doznania oraz chwile szczęścia. Dotyczy to wyłącznie głównego bohatera powieści. Davenant czerwieni się, kiedy dowiaduje się, że być może zostanie uwolniony z więzienia, ponieważ odnaleziono przyjaciół, którzy mogą mu pomóc: Вне себя от такого количества важных и поразительных сообщений, Давенант счастливо расхохотался. Крайнее возбуждение выразилось тем, что на его левой шеке проступило яркое красное пятно, захватившее угол глаза и висок (Utw. 5, 502), - Вся шека у вас стала красная, - сказал Факрегед. - Что это такое? (Utw. 5, 502).

Zmiana koloru skóry może nastąpić również wskutek działania czynników zewnętrznych. Należy zaliczyć do nich wysoką temperaturę powietrza, która spowodowała zaczerwienienie twarzy wracającego do domu Barketa: Толкнув стеклянную дверь, вошел раскрасневшийся от жары Баркет с готовой любезной ульбкой, обращенной $\kappa$ посетителю (Utw. 5, 512).

W przypadku ojca Tyrreusza zmiana kolorystyki cery w postaci czerwonych żyłek wywołana została przez nadużywanie alkoholu: $C$ первого взгляда Тиррей заметил, что отеи пьян как стелька и, вероятно, не спал. Хотя был он выбрит, умыт, его старое, в красных жилках лицо по-прежнему не внушало никакого доверия (Utw. 5, 410).

Twarz sklepikarza Stomadora ma odcień różowy, co jest spowodowane kolorem noszonej przez mężczyznę chustki: Красный с голубыми кружочками платок, которым Стомадор имел привычку обвязывать дома голову, одним углом свешивался на ухо, придавая широкому, бледному от духотьл лииу старика розовый оттенок (Utw. 5, 488).

Barwa z pola semantycznego bieli została wykorzystana przez Grina do opisu twarzy Botredge'a i Tergensa, które stawały się białe z powodu osia- 
dającego na nich pyłu wapiennego, unoszącego się podczas kopania tunelu: Волосьи и лица их стали бельми от пыли (Utw. 5, 533).

\section{Barwa oczu bohaterów powieści}

Przy pomocy nazw barw pisarz kreuje w analizowanym utworze także obrazy oczu bohaterów. Oczy są takim elementem twarzy człowieka, który odzwierciedla jego myśli i wyraża jego duszę. Określenie koloru oczu w dużym stopniu zależy od oceny osoby opisującej, od jej perspektywy i sposobu odbioru.

W Drodze do nikąd przedstawione postacie w większości przypadków mają oczy czarne bądź szare. Oczy czarne są piękne i pociągające, mogą fascynować, intrygować, ale też wywoływać niepokój i poczucie niebezpieczeństwa [Kul'pina 2001, 114]. Czarne oczy posiadają zarówno kobiety, jak i mężczyźni. Należą do nich:

- Ort Galeran - stały klient jadłodajni „Abominacja”, później przyjaciel Davenanta: Высокий лоб, изогнутые губы, длинный, как повисший Флаг, нос и черные презрительные глаза под тонкими бровями обрашали внимание женщин (Utw. 5, 347), В его черных глазах мелькала искра иронии (Utw. 5, 359),

- jedna z córek Futroza, z którymi zaprzyjaźnił się Davenant - Roena: Давенант увидел черные глаза Рой, стесненно взглянувшей на его замкнутое лицо (Utw. 5, 395),

- Consuela Juarez - narzeczona, a później małżonka Van Koneta: B общем, это была хорошенькая девушка с приветливым личом, ясными чернылми глазами и с очаровательными ресничами (Utw. 5, 451), - jego ojciec - gubernator Van Konet: Месть губернатора выразилась замкнутой ульбкой и любопьтным выражением бескровного лица; его старые черные глаза смотрели так, как смотрит женщина с большим опытом на девииу, утратившую без особой нужды первую букву своего алфавита (Utw. 5, 479),

- strażnik więzienny: Его черные небольшие глаза слегка улыбнулись, u, тихо прикрыв дверь, чтобы надзиратель общего отделения лазарета случайно не подслушал беседу (Utw. 5, 501),

- mężczyzna w przydrożnej karczmie, który pojawia się w strasznym opowiadaniu Futroza: Зрачки были черны и блестящи, как у всех нас, но не было в них той трепетной желтой точки, какая является, если против лича сияет огонь ... (Utw. 5, 388), - Вот уж! - пренебрежительно отозвалась Титания. - Две чернье пуговиць! (Utw. 5, 389). 
Dość często w opisie bohaterów pojawiają się niczym nie wyróżniające się oczy szare. Wchodząc w skład określonych związków wyrazowych, nazwa barwy szarej wskazuje na osobę poważną, cechującą się spokojem i rozwagą [Kul'pina 2001, 117]. Szare oczy ma przede wszystkim:

- główny bohater powieści - Davenant: Искренние серье глаза при полудетской линии рта и правильных чертах были его заступниками (Utw. 5, 353), Несколько раз в камеру Давенанта являлся начальник тюрьмы, мрачный седой человек с острым личом. Тщательно осмотрев камеру, окно, нехотя пробормотав: «Имеет ли заключенный претензии?» - начальник продолжительно взглядывал последний раз на замкнуто следящие за его движениями серье глаза Давенанта и ухо$\partial u л$ (Utw. 5, 500),

- kobieta, u której on wynajmował pokój: В серых глазах Губерман таилось нестерпимое любопьтство, жажда нюхать, грызть чужую жизнь (Utw. 5, 399),

- przyjaciel Roeny i Elly - Gonzac: Гонзак - рыжеватый юноша с острым личом, сероглазый, надменный, не понравился Давенанту (Utw. 5, 383),

- sklepikarz Stomador: Серые глаза, толстые, с лукавым выражением губы, кругльй, двойной подбородок и тупой нос составляли, в общем, внешность дородного монаха (Utw. 5, 488),

- sędzia śledczy badający sprawę Davenanta: Это был плотный, коренастый человек с ускользаюшим взглядом серых глаз (Utw. 5, 483).

Tylko jedna z bohaterek Drogi do nikad ma niebieskie oczy. Jest nią kochanka Van Koneta - Laura Muldway: Высокая белокурая Лаура Мульдвей, с детским лиџом и чистосердечными синими глазами, гибкостью тонкой фигуры напоминала колеблющуюся от ветерка ленту (Utw. 5, 438).

Czynniki zewnętrzne moga wywoływać zaczerwienienie oczu bohaterów. Ma to miejsce w przypadku Tergensa i Botredge'a, u których przekrwienie oczu powoduje kurz, unoszący się podczas kopania tunelu do więzienia: Прибегли к перџовке, единственно возвращающей осмысленный вид дергаюшимся небритым личам с красными от пыли глазами (Utw. 5, 539).

Leksem желтьй został wykorzystany przez autora do opisu oczu wspomnianego już wcześniej bohatera strasznego opowiadania Futroza - Silasa Genta. Są to oczy martwe, nie odbijające światła: Зрачки были черны и блестящи, как у всех нас, но не было в них той трепетной желтой точки, какая является, если против лича сияет огонь ... (Utw. 5, 388). 


\section{Barwa innych części twarzy bohaterów}

Nazwy barw w analizowanej powieści autor sporadycznie wykorzystuje do kreowania obrazów innych części twarzy bohaterów. Należy wymienić tu opis:

- czerwonego, wilgotnego nosa Hubermanowej: Чувствуя внимание сзади себя, Давенант повернулся $\kappa$ двери, где красный, слезящийся нос Губерман таился в тени (Utw. 5, 399),

- czarnych od kurzu ust Davenanta: Большое зеркало отразило понурую фигуру с бледным лицом и черным от пьли ртом (Utw. 5, 430), - zębów: białych - Stomadora i Botredge'a: Когда первые два стаканчика пролились в разинутые белозубые ртыл, Стомадор пожевал рыбку и заявил (Utw. 5, 488) i żółtych gubernatora Van Koneta: Но состояние прострачии еще не покинуло Ван-Конета, и ехидньй смешок при мысли о незавидной истории сына, вырвавшийся из желтых зубов старика, был в этот день последней данью его подагрической философии (Utw. 5, 515).

\section{Barwa włosów bohaterów}

Dość dużo uwagi Grin poświęcił kolorystyce włosów bohaterów. Powołując się na W. G. Kulpinę, należy zauważyć, że „в сфере цветообозначения волос основная дихотомия - это волосы светлые и темные" [Kul'pina 2001, 100], przy czym „черные волосы как бы выпадают из этого деления на светлые и темные волосы, потому что темные волосы - это хотя и почти черные волосы (...), но все же не черные. Поэтому когда мы говорим о волосах, что они темные, то черные волосы при этом не имеются в виду" [Kul'pina 2001, 101].

Najwięcej występujących w powieści osób autor obdarzył czarnymi włosami. Należą do nich pierwszoplanowe postacie takie jak:

- Futroz: Его черные волось спускались бакенами до срединь шек, придавая одутловатому бритому личу с большим ртом и желтым оттенком кожи характерную остроту (Utw. 5, 359),

- Consuela: Тонкая золотая чепочка, украшенная крупной жемчужиной, обнимала смуглую шею девушки двойным рядом, в черных волосах стоял черепаховый гребень (Utw. 5, 451).

Wśród postaci epizodycznych byli to:

- właściciel szynkwasu w Tachenbaku: Это был обросший чернылми волосами человек с желтым личом - итальянеи смешанной крови (Utw. 5, 509), 
- spiskowiec Dan Tergens: Не теряя времени, четьле заговоршика Галеран, Ботредж, Стомадор и Дан Тергенс, черноволосый, с кругльм личом, спокойный, как сыр, человек, - взялись за трудную работу соединения двора лавки с двором тюрьмь узкой траншеей (Utw. 5, 530),

- kolega córek Futroza - Thorton: Тортон был смугл, черноволос, девятнадиати лет, с начинающими пробиваться усами и вечной ульбкой (Utw. 5, 383).

Jasne włosy w Drodze do nikad posiadają dwie młode kobiety:

- chora na gruźlicę szwaczka Melly, którą opiekowały się Roena i Elly: Бледная, белокурая, с устальлм счастливым лищом, Мели Скорт сказала Тиррею (Utw. 5, 379),

- kochanka Van koneta - Laura: Выссокая белокурая Лаура Мульдвей, с детским личом и чистосердечными синими глазами, гибкостью тонкой фигурь напоминала колеблюшуюся от ветерка ленту (Utw. 5, 438).

Wśród bohaterów powieści znalazły się również osoby o rudych włosach. Ten kolor włosów znajduje się jakby poza podziałem na jasne i ciemne i bardziej pasuje kobietom, niż mężczyznom. U kobiet jest on intrygujący, prawie zawsze obiecujący, że kobieta z takim kolorem włosów może być interesująca [Kul'pina 2001, 105]. Właśnie taką bohaterką jest Ruda Katrin: Человек был худой, рябой, с суровым взглядом и в отличном расположении духа, так как выпил уже две бутылки местного желтого вина у инфернальной женщины по имени Катрин Рыжая, жившей неподалеку; теперь он хотел угостить Катрин на свой счет (Utw. 5, 486), Стомадор отодвинул засов и увидел рыжую молодую женшину, в распахнутой белой кофте, с яркими пятнами на щеках (Utw. 5, 490), Через Тергенса уже шли по тюрьме слухи о ссоре Гравелота с каким-то очень важным личом высшей администрачии, причем, разумеется, играла роль светская дама, но слухи эти, не принимая ни окончательной, ни достоверной формы, породили к Гравелоту симпатию, и, лишь боясь потерять место, врач не делал узнику тех существенньх одолжений, одно из которых пало на долю Катрин Рыжей (Utw. 5, 500) Как стемнело, явилась Рыжая Катрин, закурила и села (Utw. 5, 540), - Ты не рыжая, ты - золотая, - объявил Стомадор, наливая ей коньяку. - Выпей и уходи. Ну, как твой Кравар? (Utw. 5, 541), Без Факрегеда ночью в лазарете не обойтись - таково было общее мнение, переданное для разведки и разработки Ботреджу, при помощи Катрин Рыжей и Кравара (Utw. 5, 524), Рыжая Катрин и отчасти 
выручила его, взявшись торговать, а Стомадор проспал четыре чаca (Utw. 5, 533). Jej kolor włosów został opisany również przy pomocy leksemu золотой: - Ты не рыжая, ты - золотая, - объявил Стомадор, наливая ей коньяку. - Выпей и уходи. Ну, как твой Кравар? (Utw. 5, 541), А где же та, золотая ... чудесная, которую я поймал? (Utw. 5, 566).

W powieści występują także rudowłosi mężczyźni:

- nowy kelner w „Abominacji”: Новый слуга, рыжий, матерый парень, подошел было к нему (Utw. 5, 379), Давенант хотел выйти, но рыжий слуга ткнуй его слегка в бок (Utw. 5, 379), Он дал рыжему парню мелочь (Utw. 5, 380),

- Gonzac: Гонзак - рыжеватыий юноша с острым лицом, сероглазый, надменный, не понравился Давенанту (Utw. 5, 383).

Siwe włosy, z kolei, nie moga być oceniane z punktu widzenia koloru, ponieważ wskazują one na brak pigmentacji i świadczą najczęściej o wieku człowieka. Siwymi mężczyznami w powieści Grina są:

- Ort Galeran: Брови Галерана были еще черньи, но шея сделалась жилистой, волосы на голове поседели, а в глазах и складках рта светилось терпеливое доживание жизни, свойственное одиноким под старость людям (Utw. 5, 496). Jego włosy są do tego stopnia pozbawione pigmentacji, że pisarz do ich określenia używa również leksemu бельй: Сpeди газет и дамских шляп Стомадор пробрался к буфету, где первыи же служаший на его вонрос о Галеране, лишь чуть поискав глазами, указал высокого человека с белой головой, который сидел около зеркала (Utw. 5, 496), - А это кто? Это Стомадор, - продолжал Давенант, которому в его состоянии ничуть не казалась удивительной сцена, представляющая сплошной риск. - Репный пирог, Стомадор, навеки соединил нас. Орт Галеран, мой друг. Вы совсем бельй, да и я такой же внутри (Utw. 5, 546).

- właściciel „Abominacji” Kiszlot: Хозяина ресторана звали Адам Киилот. Он был грузен, подвижен, с седыми волосами артиста и дрябльмм лицом (Utw. 5, 346),

- ојсіес Davenanta: У стола сидел оборванный седой человек с тяжельљм, едким личом, подвыпивший и сгорбленныий (Utw. 5, 399), przemytnik Outlander: В нее сели четверо: Давенант, Гетрах, Петвек и шестидесятилетний седой контрабандист Утлендер (Utw. 5, 471), - naczelnik więzienia, w którym odbywał karę Davenant: Несколько раз в камеру Давенанта являлся начальник тюрьмь, мрачный седой человек с острым личом. Тщательно осмотрев камеру, окно, нехотя пробормотав: «Имеет ли заключенный претензии?» - начальник про- 
должительно взглядьввал последний раз на замкнуто следящие за его движениями серые глаза Давенанта и уходил (Utw. 5, 500).

Leksemu седеть Grin użył do opisu każdego potencjalnego człowieka, który mając do wyboru dwie drogi, wybiera tę, po której trzeba iść w górę, a nie staczać się w dół: $A$ когда в награду за это голова твоя начнет седеть и доктора захотят получать от тебя постоянную ренту за то, что ты насквозь болен, вот тогда ты почувствуешь, как тебе досталась высота положения и деньги, конечно. Да, так ради чего же ты так искалечился? (Utw. 5, 411).

Białe od wapiennego pyłu włosy mają mężczyźni, którzy kopią tunel: Волосы и лица их стали белыми от пыли (Utw. 5, 533).

\section{Barwa brwi, rzęs i zarostu u mężczyzn}

Rzadko w Drodze do nikad autor wykorzystuje nazwy barw do kreowania obrazów brwi, rzęs, czy zarostu u mężczyzn. Czarne brwi pojawiają się w opisie Orta Galerana: Брови Галерана были еще черны, но шея сделалась жилистой, волосы на голове поседели, а в глазах и складках рта светилось терпеливое доживание жизни, свойственное одиноким под старость людям (Utw. 5, 496), natomiast strażnik więzienny Krawar ma siwe brwi: За ними стоял плотный, коренастьии Кравар. Его багровое лицо с седылми бровями показалось между железных прутьев (Utw. 5, 491). Kolor rzęs został uwzględniony tylko w opisie jednego bohatera - Weissa, który pojawia się w oberży „Morze i ląd": Сногден (...), пошатыввался рядом с Вейсом, хозяином недавно прибывшей в Гертон яхты, веснушчатым сонным человеком, белье ресничь которого прикрывали нетвердый и бестолковый взгляд (Utw. 5, 438).

Dwóch mężczyzn posiada zarost - czarne wąsy. Są to:

- dozorca w szpitalu, w którym znajdował się Tyrreusz: Эmо был Факрегед, молодой человек лет тридиати, с нездоровым иветом лича и черными усиками (Utw. 5, 501),

- właściciel samochodu, którym Davenant dojechał do Lissy: - Почему ты знаешь, куда мы едем? - спросил третий, черноусый и краснощекий хозяин автомобиля (Utw. 5, 422), - А почему тьи не сел в поезд? спросил черноусый человек (Utw. 5, 422), Давенант так обрадовался, что схватил черноусого человека за локоть и сжал его, смеясь от восхищения (Utw. 5, 422). 


\section{Barwa innych części ciała}

W analizowanej powieści występuje niewiele kolorystycznych opisów innych części ciała. Należą do nich opis brudnej szyi i rąk kopiących tunel Tergensa i Botredge'a: Его ноги были по колено в белой пьли, известью захватань рукава рубашки, а шея почернела от пота; он взял лежашую в углу парусину и начал переодеваться (Utw. 5, 532), Ободранные колени, руки, черные от грязи и засыхающей крови, распухшие шеи и боль в крестце заставляли иногда то одного, то другого падать в полусознательном состоянии (Utw. 5, 542), chora noga Davenanta: Галеран откинул одеяло и тихо опустил его. Нога, надувшись, красновато блестела; ступня, слившись с икрой, потеряла форму (Utw. 5, 546) oraz paznokcie jego ојса: Вдавив табак в трубку желтым, как луковая шелуха, ногтем большого пальча, отеи еще раз взглянул на сына поверх поднесенной $\kappa$ трубке горящей спички (Utw. 5, 402).

\section{Barwa ubiorów bohaterów}

W porównaniu z bogactwem użyć nazw barw w utworze, strefa słownictwa dotyczącego nazw barw ubiorów jest uboższa. Niemniej jednak, praktycznie w każdym opisie elementów odzieży bohaterów występują określenia kolorów, co pozwala dokładniej zrozumieć i wyobrazić sobie nastrój i sytuację, w której znajduje się przedstawiona postać. Epitety barwne wyróżniają zarówno ubiory damskie, jak i męskie. Należą do nich:

a) sukienka:

- biała sukienka Marty: Гуг Бурк вернется из плавания, и тогда мы нарядим Марту в белое платье... (Utw. 5, 441),

- czarna sukienka Consueli: На счастье Галерана, а также обоих надзирателей, переживших за эту ночь столько волнений, сколько не испьтали за всю жизнь, Давенант бредил лишь об утешении. По его словам, оно являлось к нему в черном кружевном платье и плакало (Utw. 5, 567);

b) biała bluzka:

- Katrin: Стомадор отодвинул засов и увидел рыжую молодую женшину, в распахнутой белой кофте, с яркими пятнами на шеках (Utw. 5, 490), - Ждите, - кинула она, стреляя белой кофтой в темную ночь (Utw. 5, 491),

- Consueli: Для этого свидания Консуэло выљрала белую блузку с от- 
ложным воротником и яркую, как пион, юбку; на ее маленьких ногах бьли чернье туФли и белье чулки (Utw. 5, 451);

c) zielony żakiecik Laury Muldway: Зеленьй жакет, серая шляпа с бельм пером и серье туфельки Лаурь стеснили Марте дьхание (Utw. 5, 438);

d) garnitury Davenanta:

- biały: Рядом висят части белого костюма и четьре галстука различных оттенков (Utw. 5, 369), Сняв серьй костюм, Давенант облачился в бельй (Utw. 5, 372), Вылив кофе и закусив, Давенант оделся в бельй костюм (Utw. 5, 372), Еәо бельй костюм не обманул проницательность Мели Скорт (Utw. 5, 376), Он вошел к себе и увидел раскрытый шкаф; бельий костюм и белье исчезли (Utw. 5, 413),

- szary: Отрылистый голос заканчивал этот облик, за исключением не упомянутого нами серого костюма и манеры дергать иногда левой рукой пуговичу жилета (Utw. 5, 359), Примерил серьий костюм; нигде не жало, жилет не теснил грудь (Utw. 5, 372), Сняв серый костюм, Давенант облачился в бельй (Utw. 5, 372), Он был под влиянием замысла продать свой серый костюм и вьитрать сто фунтов, чтобь его отеи, получив деньги, оставил город (Utw. 5, 415), Тиррей разьскал лавку, сторговался продать костюм за два фунта и, вернувшись домой, переоделся в старое платье, а серый костюм завернул в газету и отнес в лавку (Utw. 5, 415) oraz granatoшу: У него был старенький синий костюм, купленный за гроши на деньги первого жалованья, и соломенная шляпа с порыжевшей лентой (Utw. 5, 357); biała koszula Davenanta: Тиррей увидел человека в грязной белой рубашке, с постным лииом и толстой нижней губой (Utw. 5, 406);

e) marynarki:

- granatowa Tyrreusza: Наконеи, опомнясь, он ушел заменить синий пиджак белой рабочей курткой (Utw. 5, 365),

- szary surdut Galerana: Галеран носил широкополую белую шляпу, серыий сюртук и сапоги до колен, а шею повязывал желтыл платком (Utw. 5, 348);

f) spodnie:

- szare Davenanta: - Tbь видишь, - продолжал, Галеран тоном ботаника, объясняющего разрез иветка, - тьл видишь здесь части нового костюма, состоящего из серых брюк, жилета и пиджака, - это довольно дорогое сукно (Utw. 5, 369),

- czarne jego ојса: Одетьй в рваную матросскую фуфайку, когда-то синей, а теперь грязно-голубой фланели, ластиковые чернье брю- 
ки, заплатаннье на коленях квадратами, вшитыли старательно, но криво, как штопают мужчинь, вьнужденные судьбой носить в кармане иголку и нитки, Франк Давенант, согнувшись, сидел у стола (Utw. 5, 401);

g) kurtki:

- biała Tyrreusza: Наконец, опомнясь, он ушел заменить синий пиджак белой рабочей курткой (Utw. 5, 365),

- brunoniebieska jego ојса: Одетый в рваную матросскую фуфайку, когда-то синей, а теперь грязно-голубой фланели, ластиковье чернье брюки, заплатаннье на коленях квадратами, вшитьми старательно, но криво, как штопают мужчинь, вынужденные судьбой носить в кармане иголку и нитки, Франк Давенант, согнувшись, сидел y стола (Utw. 5, 401);

h) białe stroje Roeny i Elly: Галеран задумчиво наблюдал эту сцену, а Давенант смутился, увидев девушек, несомненно принадлежащих $\kappa$ обществу, красивых и смеюшихся, одетых в белье костюмь, бельєе шляпь, белье чулки и туфли, под зонтиками вишневого цвета (Utw. 5, 349);

i) kapelusze:

- biały Galerana: Галеран носил широкополую белую шляпу, серьй сюртук и сапоги до колен, а шею повязывал желтым платком (Utw. 5, 348),

- białe Roeny i Elly: Галеран задумчиво наблюдал эту сиену, а Давенант смутился, увидев девушек, несомненно принадлежаших $к$ обшеству, красивых и смеюшихся, одетьх в белье костюмь, белье шляпь, белье чулки и туфли, под зонтиками вишневого ивета (Utw. $5,349)$,

- szary z białym piórkiem Laury: Зеленьй жакет, серая шляпа с бельљм пером и серье туфельки Лаурь стеснили Марте дыхание (Utw. 5, 438), - słomkowy z wyrudziałą wstążką Tyrreusza: $У$ него бъл старенький синий костюм, купленньй за гроши на деньги первого жалованья, и соломенная шляпа с порыюевшей лентой (Utw. 5, 357);

j) szara bluza Stomadora: Передник, завязанньй под мьиками, засученные рукава серой блузы, короткие темные итаны и кожаные туфли - все бьло уместно на Стомадоре, все - кстати его личу (Utw. 5, 488);

k) czarna mantyla Consueli: Почти не бъло прохожих в этот час ночи; на коние бульвара одна явственная женская фигура в черной мантилье приближалась $\kappa$ ступеням; как звездь, блеснули ее глаза (Utw. 5, 551); 
l) białe pończochy:

- Roeny i Elly: Галеран задумчиво наблюдал эту сиену, а Давенант смутился, увидев девушек, несомненно нринадлежащих к обществу, красивых и смеюшихся, одетых в белье костюмы, белье иляпы, белье чулки и туфли, под зонтиками вишневого ивета (Utw. 5, 349), - Consueli: Для этого свидания Консуэло выбрала белую блузку с отложныл воротником и яркую, как пион, юбку; на ее маленьких ногах были чернье туфли и белье чулки (Utw. 5, 451);

ı) pantofle:

- białe córek Futroza: Галеран задумчиво наблюдал эту сцену, а Давенант смутился, увидев девушек, несомненно принадлежащих к обществу, красивых и смеюшихся, одетьх в белье костюмьи, белье иляпь, белье чулки и туфли, под зонтиками вишневого цвета (Utw. 5, 349), - czarne Consueli: Для этого свидания Консуэло выбрала белую блузку с отложньл воротником и яркую, как пион, юбку; на ее маленьких ногах бьли чернье туфли и белье чулки (Utw. 5, 451),

- szare Laury: Зеленый жакет, серая шляпа с бельм пером и серые туфельки Лауры стеснили Марте дыхание (Utw. 5, 438);

m) dodatki:

- chustki - czerwona w błękitne kółka Stomadora: Красный с голубыми кружочками платок, которым Стомадор имел привычку обвязывать дома голову, одним углом свешивался на ухо, придавая широкому, бледному от духоты личу старика розовый оттенок (Utw. 5, 488) i żółta Galerana: Галеран носил широкополую белую шляпу, серый сюртук и сапоги до колен, а шею повязывал желтылм платком (Utw. 5, 348),

- czerwone parasolki córek Futroza: Иногда он видел Кишлота и красные зонтики девочек, смеющихся так, что все смеялось вокруг (Utw. 5, 501), Галеран задумчиво наблюдал эту сиену, а Давенант смутился, увидев девушек, несомненно нринадлежащих к обществу, красивых и смеюшихся, одетых в белье костюмы, белье иляпь, белье чулки и туфли, под зонтиками вишневого цвета (Utw. 5, 349).

\section{Stany psychiczno-emocjonalne bohaterów wyrażone przy pomocy barw}

Dość skromny jest zakres barw określających stany psychiczno-emocjonalne bohaterów Drogi do nikad. Autor przedstawił życie duchowe tylko jednej z postaci - Tyrreusza Davenanta, który porównuje swoje wnętrze do 
białych włosów Orta Galerana: - A это кто? Это Стомадор, - продолжал Давенант, которому в его состоянии ничуть не казалась удивительной сцена, представляющая сплошной риск. - Репный пирог, Стомадор, навеки соединил нас. Орт Галеран, мой друг. Вы совсем бельй, да и я такой же внутри (Utw. 5, 546). Siwe włosy - to włosy wybarwione, nie posiadające koloru. Tak samo bezbarwne i bezsensowne są ostatnie dni życia głównego bohatera. Białe włosy świadczą o tym, że prawie wszystko w życiu już zostało przeżyte, kończy się też przegrane życie Davenanta. Był on człowiekiem dobrym, który kierował się uczuciami i honorem. Życie go nie rozpieszczało, a mimo to był gotów pomagać innym, stawać w obronie potrzebujących. Stomador określa dobro Tyrreusza poprzez przeciwstawienie, używając leksemu черньй, który jednoznacznie konotuje zło [Tokarski 2004, 44-46]: Вот его последнее желание, и судите, может ли так сказать черная душа (Utw. 5, 552).

\section{Podsumowanie}

Paleta barw używanych przez A. Grina do opisu postaci w Drodze do nikad jest dość uboga, nie ma tu prawie zupełnie odcieni, barw niejednolitych i mieszanych.

Tabela 1. Klasy wyrazów odnoszących się do barw

\begin{tabular}{|c|c|c|c|c|c|}
\hline Pole & Przymiotniki & Imiesłowy & Przysłowki & Czasowniki & $\begin{array}{c}\text { Liczba } \\
\text { wystąpień }\end{array}$ \\
\hline Czerwień & $\begin{array}{l}\text { красный }(9 x), \\
\text { рыжий }(11 x), \\
\text { багровый }(5 x), \\
\text { розовый }(2 x), \\
\text { красноще- } \\
\text { кий }(1 \mathrm{x}), \\
\text { рыжеватый }(1 \mathrm{x}) \\
\text { вишневый }(1 \mathrm{x})\end{array}$ & $\begin{array}{l}\text { краснея }(2 \mathrm{x}), \\
\text { краснею- } \\
\text { щий }(1 \mathrm{x}), \\
\text { раскрасневший- } \\
\text { ся }(1 \mathrm{x}),\end{array}$ & красновато $(1 \mathrm{x})$ & покраснеть (8x) & 43 \\
\hline Biel & $\begin{array}{l}\text { белый }(24 x), \text { бе- } \\
\text { локурый }(2 x), \\
\text { белозубый }(1 \mathrm{x})\end{array}$ & & & & 27 \\
\hline Czerń & $\begin{array}{l}\text { черный }(21 \mathrm{x}), \\
\text { черноусый }(3 \mathrm{x}) \text {, } \\
\text { черноволо- } \\
\text { сый }(2 \mathrm{x})\end{array}$ & & & почернеть (1x) & 27 \\
\hline
\end{tabular}




\begin{tabular}{|c|c|c|c|c|c|}
\hline Pole & Przymiotniki & Imiesłowy & Przysłowki & Czasowniki & $\begin{array}{c}\text { Liczba } \\
\text { wystąpień }\end{array}$ \\
\hline Szarość & $\begin{array}{l}\text { серый }(15 \mathrm{x}), \text { се- } \\
\text { дой }(6 \mathrm{x}), \\
\text { сероглазый }(1 \mathrm{x})\end{array}$ & & & $\begin{array}{l}\text { седеть }(1 \mathrm{x}), \\
\text { поседеть }(1 \mathrm{x})\end{array}$ & 24 \\
\hline Żółcień & $\begin{array}{l}\text { желтый }(6 \mathrm{x}) \\
\text { золотой }(3 \mathrm{x})\end{array}$ & & & & 9 \\
\hline Błękit & $\begin{array}{l}\text { синий }(4 \mathrm{x}), \text { го- } \\
\text { лубой }(1 \mathrm{x}), \\
\text { грязно-голу- } \\
\text { бой }(1 \mathrm{x})\end{array}$ & & & & 6 \\
\hline Zieleń & зеленый $(1 \mathrm{x})$ & & & & 1 \\
\hline $\begin{array}{c}\text { Liczba } \\
\text { wystąpień }\end{array}$ & 121 & 4 & 1 & 11 & 137 \\
\hline$\%$ & $88 \%$ & $3 \%$ & $1 \%$ & $8 \%$ & $100 \%$ \\
\hline
\end{tabular}

Użyte w powieści wyrazy, odnoszące się do barw, reprezentują siedem pól: pole czerwieni, bieli, czerni, szarości, żółcienia, błękitu i zieleni i są wyrażone różnymi częściami mowy: przymiotnikami (121), czasownikami (11), imiesłowami (4) i przysłówkami (1). Wysoką frekwencją, co wskazuje na rangę koloru w powieści, charakteryzują się cztery pierwsze pola. We wszystkich polach dominują przymiotniki $(88 \%)$. Niewątpliwie jest to związane z główną funkcją wyrazów odnoszących się do barw - nazywaniem cech.

Tabela 2. Zakres użycia nazwy barw

\begin{tabular}{|l|c|c|c|c|c|c|}
\hline \multirow{2}{*}{ Pole } & \multicolumn{2}{c|}{$\begin{array}{c}\text { Wygląd zewnętrzny } \\
\text { bohaterów }\end{array}$} & \multicolumn{2}{c|}{ Opis ubiorów } & \multicolumn{2}{c|}{$\begin{array}{c}\text { Charakterystyka } \\
\text { wewnętrzna bohaterów }\end{array}$} \\
\cline { 2 - 7 } & Ilość & $\%$ & Ilość & $\%$ & Ilość & $\%$ \\
\hline Czerwień & 39 & $28,5 \%$ & 4 & $3,5 \%$ & - & - \\
\hline Biel & 9 & $6,5 \%$ & 17 & $12,5 \%$ & 1 & $1 \%$ \\
\hline Czerń & 21 & $15 \%$ & 5 & $3 \%$ & 1 & $1 \%$ \\
\hline Szarość & 14 & $10 \%$ & 10 & $7 \%$ & - & - \\
\hline Żółcień & 7 & $5 \%$ & 2 & $1,5 \%$ & - & - \\
\hline Błękit & 1 & $1 \%$ & 5 & $3,5 \%$ & - & - \\
\hline Zieleń & - & - & 1 & $1 \%$ & - & - \\
\hline \multicolumn{1}{|c|}{ Ogółem } & 91 & $66 \%$ & 44 & $32 \%$ & 2 & $2 \%$ \\
\hline
\end{tabular}


Największą liczbę nazw barw w analizowanej powieści pisarz wykorzystał do opisu wyglądu zewnętrznego występujących postaci (66\%), używając przede wszystkim kolorów z pola czerwieni (28\%), czerni (15\%) i szarości $(10 \%)$. Chociaż wygląd zewnętrzny bohaterów powieści jest bardzo różny, to w ich opisach występują również cechy wspólne - na ich twarzach rysują się rumieńce wywołane różnymi przeżyciami, wielu z nich ma czarne oczy i czarne, siwe lub rude włosy. Jako określenia ubiorów najczęściej pojawiają się biel $(12,5 \%)$ i szarość $(7 \%)$, natomiast nazwy barw w opisach wnętrza postaci występują sporadycznie.

\section{Literatura}

Siekierska K., 1988, Kolorystyczna charakterystyka postaci Trylogii Henryka Sienkiewicza, „Poradnik Językowy”, z. 3, s. 177-193.

Spólnik A., 1994, Kolor w opisie postaci (na podstawie Gloria Victis Elizy Orzeszkowej), (w:) Od strony Kresów: studia i szkice, Kraków, s. 149-154.

Tokarski R., 2004, Semantyka barw we wspótczesnej polszczyźnie, Lublin.

Vaňková I, 2000, Mienić się różnymi kolorami, (w:) Studia z semantyki porównawczej, cz. 1., pod red. R. Grzegorczykowej i K. Waszakowej, Warszawa, s. $105-123$.

Gajdukova T.M., 2008, Cvetooboznačeniâ čeloveka i častejego tela (na materiale sovremennogo nemeckogo âzyka): dis. ... kand. filol.nauk 10.02.04, N. Novgrod. [Гайдукова Т.М., 2008, Цветообозначения человека и частей его тела (на материале современного немецкого языка): дис. ... канд. филол. наук 10.02.04, Н. Новгрод.]

Gelâeva A.I., 2002, Čelovek kak ob"ekt nominacii vâzykovoj kartine mira: dis. ... kand. filol. nauk 10.02.19, Nal'čik. [Геляева А.И., 2002, Человек как объект номинации в языковой картине мира: дис. ... канд. филол. наук 10.02.19, Нальчик.]

Grin A.S., Sobranie sočinenij, tom pâtyj, Moskva 1997 [Грин А.С., Собрание сочинений, том пятый, Москва 1997.] (Utw. 5)

Kul'pina V.G., 2001, Lingvistika cveta: Terminy cveta vpol'skom $i$ russkom âzykah, Moskva. [Кульпина В.Г., 2001, Лингвистика ивета: Термины ивета в польском и русском языках, Московский Лицей, Москва, с. 89.]. 


\title{
COLOR IN HUMAN'S CHARACTERISTIC \\ (ON WAY TO NOWHERE BY ALEXANDER GRIN)
}

\author{
S U M M A R Y
}

Key words: Grin, idiolect, color semantics, characters' colors

Color is one of the artistic means, by which text can be perceived as an artistic whole. The aim of this paper is to analyze the names of colors used to describe human space in Way to nowhere by Alexander Grin. The color nominations refer to description of human external appearance and clothing. They are expressed by one-word names (красньй, бельии), names derived from them (покраснеть, почернеть) and compound words (черноволосылй, черноусый). In order to define the human color space, the author used 137 lexemes, which belong to serval color fields: красньии, бельии, черный, серый, желтый, синий and зеленьии. Undoubtedly, all of them express national and individual priorities. 